\title{
Mature Cystic Teratoma of Ovary with Abnormally High Levels of Ca19-9: A Case Report
}

\section{Teratoma maduro cístico do ovário com níveis aberrantes de Ca19-9: caso clínico}

\author{
Joana Sampaio $^{1}$ Inês Sarmento-Gonçalves ${ }^{1} \quad$ Joana Moreira Barros $^{1} \quad$ Joana Felix $^{1} \quad$ Pedro Tiago-Silva $^{1}$ \\ ${ }^{1}$ Department of Gynecology and Obstetrics, Hospital Pedro Hispano, \\ Senhora da Hora, Porto, Portugal \\ Address for correspondence Joana Sampaio, Resident, Hospital Pedro \\ Hispano, Rua Dr. Eduardo Torres, Senhora da Hora, Porto, Portugal \\ (e-mail: j_nsampaio@hotmail.com).
}

Rev Bras Ginecol Obstet 2016;38:365-367.
Abstract
Keywords
- Ca19-9
- tumor markers
- mature cystic teratoma
- ovarian teratoma
- dermoid cyst

\section{Resumo}

\section{Palavras-chave}

- Ca19-9

- marcadores tumorais

- teratoma maduro cístico

- teratoma ovárico

- quisto dermoide
Mature cystic teratomas, or dermoid tumors, are the most common benign ovarian neoplasms in young women. Malignant transformation is rare, and occurs in less than $2 \%$ of the cases. The heterogeneous histological composition of these tumors may be responsible for the occasional elevation of various tumor markers, such as Ca19-9 and Ca125. We describe one case of mature cystic teratoma in a 50-year old woman with the second highest level of Ca19-9 (8922.76 UI/mL) described in the literature. We concluded that abnormal levels of Ca19-9 are not necessarily associated with ovarian malignancy, and may lead to unnecessary medical intervention and patient anxiety. Therefore, the clinical features, imaging studies and antigen testing should be interpreted carefully, and should not limit the surgical approach.

Os teratomas maduros císticos do ovário, ou tumores dermoides, são as neoplasias benignas mais frequentes em mulheres jovens. A sua transformação maligna é rara, e ocorre em menos de $2 \%$ dos casos. A composição histológica heterogénea destes tumores pode ser responsável pela ocasional elevação de marcadores tumorais, como o Ca19-9 e o Ca125. Descrevemos um caso de teratoma maduro cístico do ovário numa paciente de 50 anos com o segundo valor mais elevado de Ca19-9 (8922,76 UI/mL) descrito na literatura. Concluímos que níveis anormalmente elevados de Ca19-9 não estão necessariamente associados a tumores malignos, e podem conduzir a intervenções médicas desnecessárias e contribuir para o aumento da ansiedade da paciente. Portanto, as características clínicas, os estudos imagiológicos e os marcadores tumorais devem ser interpretados cuidadosamente, e não devem limitar o tipo de conduta cirúrgica.

\section{Introduction}

Mature cystic teratoma (MCT), or dermoid tumor, was described for the first time 300 years ago, and is the most common ovarian tumor in adolescents and young women. ${ }^{1}$ It accounts for $10-25 \%$ of all ovarian neoplasms, and $60 \%$ of all benign ovarian tumors. ${ }^{2,3}$ Although most women presenting MCT are asymptomatic, $\sim 20 \%$ can have complications such as torsion, rupture, infection and malignant transformation $(0,17-3 \%$ of cases). ${ }^{4,5}$ MCTs are composed of one or more of the three well differentiated tissues derived from the ectoderm, mesoderm and/or endoderm germ layers. This heterogeneous composition received

March 2, 2016

accepted

June 10, 2016

published online

July 23, 2016
DOI http://dx.doi.org/

10.1055/s-0036-1586161. ISSN 0100-7203.
Copyright $\odot 2016$ by Thieme Publicações License terms

Ltda, Rio de Janeiro, Brazil
(요 (1) $\Theta$ 
may be responsible for the occasional elevation of various tumor markers, such as cancer antigen (Ca) 19-9 and Ca125. ${ }^{6}$

Cancer antigen 19-9 (also called sialylated Lewis(a) antigen) is located in the cell membrane, and undergoes various alterations during the process of cell differentiation and/or malignant transformation. ${ }^{7}$ It is most frequently raised in patients with malignancies of the pancreas, biliary tract, colon, esophagus and liver, but it can also be elevated in benign conditions, and has been suggested recently as a potential marker for the diagnosis of ovarian MCT. ${ }^{5}$

To the extent of our knowledge, we describe a case of MCT with the second highest level of the serum Ca19-9 described in literature. ${ }^{8}$

\section{Case Presentation}

A 50-year-old, premenopausal healthy woman, G1P1 (caesarean section), presented to our hospital with abdominal cramping and right abdominal pain with one week of evolution and recent worsening. Her medical history included chronic hypertension without any other clinically relevant history. Physical examination revealed a large and firm left pelvic mass occupying the left adnexal area, and the pouch of Douglas displacing the uterus to the right side. A pelvic ultrasound showed an adnexal mass with $74 \times 63 \mathrm{~mm}$ with echogenic areas suggestive of MCT of the left ovary. The patient's complete blood count and reactive protein$C$ were within the normal range. She was admitted to our service due to severe abdominal pain, and with the aim of performing further imaging and laboratory tests to clarify the origin of the mass. A pelvic magnetic resonance imaging (MRI) scan showed a multiloculated left pelvic mass with $95 \times 70$ $\times 67 \mathrm{~mm}$ with areas of fat density and proteinaceous content (-Fig. 1). A computed tomography (CT) scan revealed the same mature mass with $107 \times 77 \mathrm{~mm}$ with abundant fat content (-Fig. 2). Tumor markers were within the normal parameters

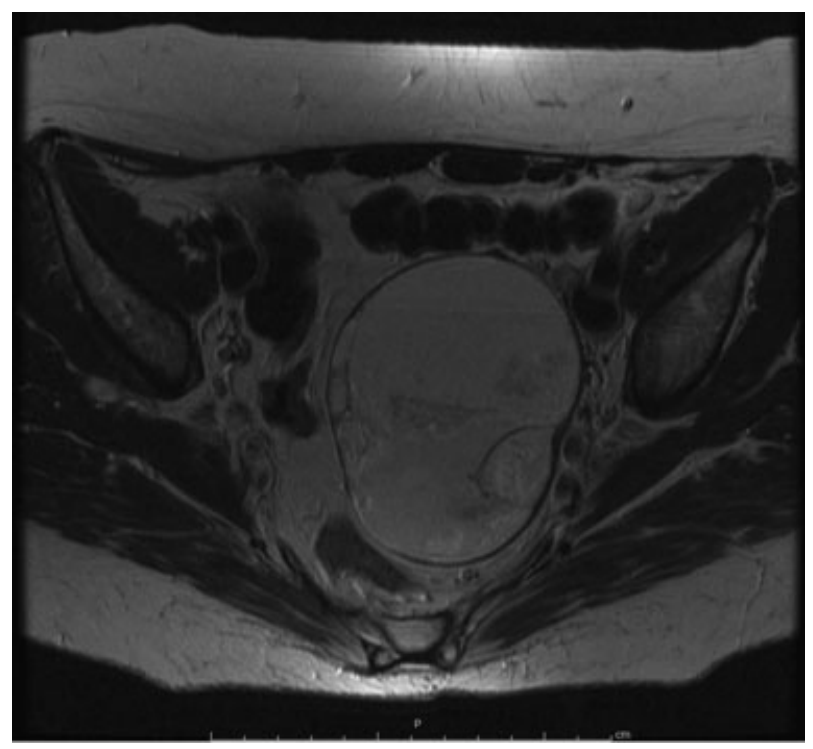

Fig. 1 T2-weighted magnetic resonance image - Multiloculated left pelvic mass with $95 \times 70 \times 67 \mathrm{~mm}$ with areas of fat density and proteinaceous content.

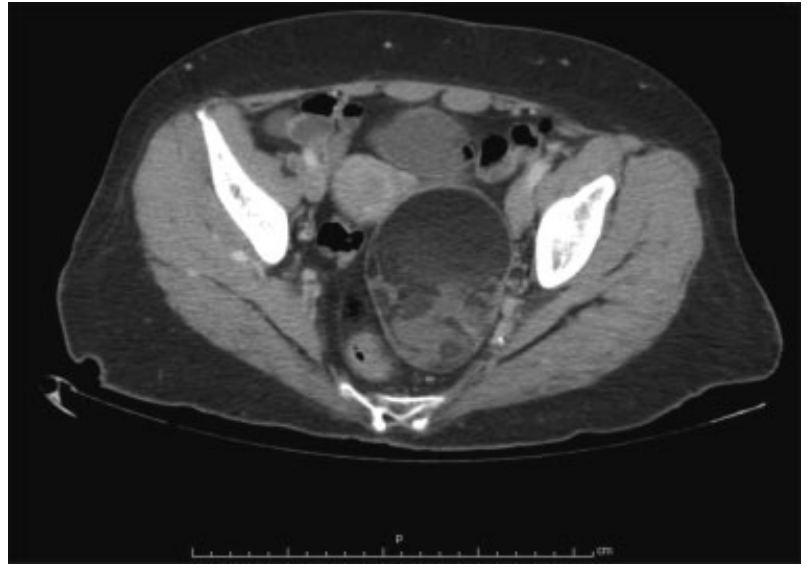

Fig. 2 CT scan image - Left adnexal mass with $102 \times 77 \mathrm{~mm}$ with heterogeneous content and abundant fat component.

(Ca15.3-9.2 UI/mL; $\alpha$-fetoprotein - $0.76 \mathrm{ng} / \mathrm{mL} ; \beta$ human chorionic gonadotropin $-<1.2 \mathrm{mUI} / \mathrm{mL}$; and Ca125-14.1 UI/ $\mathrm{mL}$ ), except for Ca19-9, which was markedly raised (8922.76 UI/ $\mathrm{mL}$ ). Upper gastrointestinal endoscopy and total colonoscopy did not show signs of gastrointestinal malignancy.

As we strongly believe that experienced imagiologists can reliably make the diagnosis of MCT based on MRI and CT scans, and after the exclusion of a gastrointestinal malignancy, we decided to perform an exploratory laparotomy with peritoneal lavage. During the procedure we found a $10 \mathrm{~cm}$ solid mass replacing the left ovary. The intraoperative histologic diagnosis revealed a mature cystic teratoma. We performed a total abdominal hysterectomy with bilateral salpingo-oophorectomy. Extensive histologic sectioning confirmed this diagnosis. The postoperative period was uneventful, and Ca19-9 returned to its normal levels.

\section{Discussion}

Mature cystic teratomas are ovarian germ cell tumors believed to arise from the primordial germ cells by failure of meiosis II or from a pro-meiotic cell in which meiosis has failed. These tumors are composed of tissues originated in all germ cell layers, and therefore various malignancies may rise in any of these layers. ${ }^{1}$ Considering these histological features, it is not surprising that Ca19-9 and Ca125 can be raised in patients presenting MCT., ${ }^{5,9}$ The rate of elevation of tumor markers Ca19-9 and Ca125 in MCTs has been reported to range from 39.6 to $59 \%$ and 13.5 to $25 \%$ respectively. ${ }^{5,10}$ However, markedly raised levels of Ca19-9 (greater than 1,000 mUI/mL) are almost always observed in the advanced stage of malignancy. ${ }^{11}$ Nevertheless, Ustunyurt et al suggest that Ca19-9 is a potential marker for the diagnosis of MCT. ${ }^{9}$

The diagnosis of these tumors is not difficult in the majority of cases. Computed tomography and MRI imaging present high sensitivity for fat and calcification, which represent the most common features of MCTs. ${ }^{12}$ Despite the specific characteristics of dermoid tumors in pelvic imaging studies, making a definitive diagnosis is sometimes difficult, and $\sim 30 \%$ of them are not apparent in the pelvic 
ultrasound. $^{5}$ Some intrinsic sonographic features of cystic teratomas can act as confounding factors, and more than $80 \%$ of these tumors present an echo pattern that can suggest malignancy, creating difficulties to differentiate a benign mass from an ovarian malignancy. ${ }^{12}$ Furthermore, other common findings, such as their large diameters and occasionally raised tumor markers, make the differential diagnosis even more difficult. ${ }^{5}$ We must also keep in mind that the malignant transformation of MCT, most frequently in invasive squamous cell carcinoma, but also in adenocarcinoma, sarcoma, carcinoid, thyroid carcinoma and melanoma, although rare (less than $2 \%$ of cases), can also be associated with the elevation of tumor markers, such as Ca19-9. ${ }^{13,14}$ Nevertheless, when the nature of a pelvic mass cannot be determined by imaging study alone, Ca19-9 testing might be a helpful tool to assist MCT diagnosis. ${ }^{5}$

Some retrospective studies have been conducted in the last years with the objective of associating the elevation of serum Ca19-9 with specific clinical features of MCTs. Dede et $\mathrm{al}^{6}$ retrospectively evaluated 80 cases of MCTs and concluded that patients with elevated Ca19-9 levels have greater tumor sizes, though the difference was statistically not significant. Another work from Cho et $\mathrm{al}^{5}$ reviewed the clinical features of 239 patients with pathologically confirmed MCTs, and demonstrated a significant correlation between Ca19-9 level, tumor size and fat component. However, Frimer et $\mathrm{al}^{15}$ failed to demonstrate any relationship between Ca19-9 and any meaningful clinical parameters. Ulkumen et $\mathrm{al}^{3}$ suggest that the correlation between high serum antigen levels and tumor size is due to leakage from the cyst wall into the bloodstream, as a result of the rupture of its weakened wall caused by the large diameter of the lesion. The rise in tumor marker concentration may also be related to ovarian torsion and to the extent of the necrosis of the ovary. ${ }^{3}$ Only a few reports have suggested that this antigen might have been stimulated by the inflammatory change due to the ischemic reaction after the torsion, and might predict the extent of tissue necrosis. ${ }^{10}$ Cancer antigen $19-$ 9 can be a particularly good marker for the evaluation of ovarian torsion and the extensity of ovarian necrosis, whose early detection is of great importance. ${ }^{3,5}$

The published studies have demonstrated that malignant transformation is not related to serum Ca19-9 elevation, and that its high levels in women with MCT of the ovary are not associated with malignant transformation. ${ }^{10}$

Some authors support the combined use of Ca19-9 and Ca125 as a useful tool for determining the nature of a pelvic mass with associated high levels of the serum Ca19-9.5,10,15 Furthermore, Ca19-9 levels can be used as a marker for postoperative follow-up in benign diseases, and as a marker for recurrence of mature cystic teratomas. ${ }^{4,7}$

In conclusion, abnormal levels of Ca19-9 are not necessarily associated with ovarian malignancy, and may lead to unnecessary medical intervention and patient anxiety. We described one case of unilateral MCT with the second highest concentration of Ca19-9 (8922.76 UI/mL) published in literature, with no signs of torsion or necrosis.

Although several studies have been published, a correlation between the clinical features of MCT and the elevation of serum tumor markers has not yet been established. We believe that an isolated increase of serum Ca19-9 is not rare, and is not associated with malignant transformation. Therefore, the clinical features, imaging studies and antigen testing should be interpreted carefully, and should not limit a minimally invasive surgical approach.

\section{References}

1 Park CH, Jung MH, Ji YI. Risk factors for malignant transformation of mature cystic teratoma. Obstet Gynecol Sci 2015;58(6): 475-480

2 Atabekoğlu C, Bozaci EA, Tezcan S. Elevated carbohydrate antigen 19-9 in a dermoid cyst. Int J Gynaecol Obstet 2005;91(3):262-263

3 Ulkumen BA, Goker A, Pala HG, Ordu S. Abnormal elevated Ca 199 in the dermoid cyst: a sign of the ovarian torsion? Case Rep Obstet Gynecol 2013;20(13):860-505

4 Madaan M, Puri M, Sharma R, Kaur H, Trivedi SS. Unusually high levels of Ca19-9 associated with mature cystic teratoma of the ovary. Case Rep Obstet Gynecol 2014;2014:187910

5 Cho HY, Kim K, Jeon YT, Kim YB, No JH. CA19-9 elevation in ovarian mature cystic teratoma: discrimination from ovarian cancer - CA19-9 level in teratoma. Med Sci Monit 2013; 19:230-235

6 Dede M, Gungor S, Yenen MC, Alanbay I, Duru NK, Haşimi A. CA199 may have clinical significance in mature cystic teratomas of the ovary. Int J Gynecol Cancer 2006;16(1):189-193

7 Ito K. CA19-9 in mature cystic teratoma. Tohoku J Exp Med 1994; 172(2):133-138

8 Kataoka T, Watanabe Y, Hoshiai H. Retrospective evaluation of tumor markers in ovarian mature cystic teratoma and ovarian endometrioma. J Obstet Gynaecol Res 2012;38(8):1071-1076

9 Ustunyurt E, Gungor T, Iskender C, Ustunyurt BO, Bilge U, Mollamahmutoglu L. Tumor markers in mature cystic teratomas of the ovary. Arch Gynecol Obstet 2009;279(2):145-147

10 Suh DS, Moon SH, Kim SC, Joo JK, Park WY, Kim KH. Significant simultaneous changes in serum CA19-9 and CA125 due to prolonged torsion of mature cystic teratoma of the ovary. World J Surg Oncol 2014;12:353

11 Pyeon SY, Park JY, Ki KD, Lee JM. Abnormally high level of CA-19-9 in a benign ovarian cyst. Obstet Gynecol Sci 2015;58(6):530-532

12 Saba L, Guerriero S, Sulcis R, Virgilio B, Melis G, Mallarini G. Mature and immature ovarian teratomas: CT, US and MR imaging characteristics. Eur J Radiol 2009;72(3):454-463

13 Parithivel K, Jagannathan JP, Krajewski K, et al. Ovarian squamous cell carcinoma arising from mature cystic teratoma. Cancer Imaging 2011;11:67-69

14 Kudva R, Ayachit GS, Ayachit A. Malignant melanoma arising in an ovarian mature cystic teratoma - a rare entity. J Clin Diagn Res 2015;9(4):ED14-ED16

15 Frimer M, Seagle BLL, Chudnoff S, Goldberg GL, Shahabi S. Role of elevated cancer antigen 19-9 in women with mature cystic teratoma. Reprod Sci 2014;21(10):1307-1311 